Praca oryginalna/Original paper

\title{
Testy kontroli jakości obrazowania megawoltowego akceleratora TomoTherapy oraz ich ocena w oprogramowaniu ARTISCAN do półautomatycznej analizy obrazów
}

\section{Quality assurance tests of megavoltage imaging in TomoTherapy accelerator and semi-automatic analysis of the image with ARTISCAN software}

\author{
Piotr Romański, Bartosz Pawałowski, Dawid Radomiak, \\ Krzysztof Matuszewski, Hubert Szweda \\ ${ }^{1}$ Zakład Fizyki Medycznej, Wielkopolskie Centrum Onkologii ul. Garbary 15 61-866 Poznań, Polska
}

\section{Streszczenie}

Stosowanie megawoltowej tomografii komputerowej (Megavoltage Computed Tomography - MVCT) w aparatach TomoTherapy wymaga testowania poprawności działania systemu detekcyjnego. Prawidłowa praca detektora warunkuje precyzyjne ułożenie chorego na stole terapeutycznym oraz dokładne dostarczenie zaplanowanej dawki do napromienianego obszaru poprzez precyzyjne odwzorowanie kształtu planowanej objętości terapeutycznej (Planning Target Volume - PTV) oraz narządów krytycznych. Kontrola jakości (Quality Assurance-QA) pracy detektora jest zatem niezbędna dla zapewnienia poprawności realizacji planów leczenia. Do analizy danych otrzymanych z testów coraz częściej wykorzystuje się programy komputerowe. Celem niniejszej pracy było uzasadnienie wdrożenia oprogramowania ARTISCAN do półautomatycznej analizy parametrów MVCT oraz wskazanie sposobu wyznaczenia tolerancji i ich ustalenie dla wybranych własności fizycznych opisujących jakość obrazów tomograficznych oraz określenie ich precyzji.

\footnotetext{
Abstract

Adres do korespondencji

Piotr Romański

Zakład Fizyki Medycznej,

Wielkopolskie Centrum Onkologii, ul. Garbary 15, 61-866 Poznań, Polska

Telefon. +48618850 552

e-mail: piotr.romanski@wco.pl
}

The common use of megavoltage computed tomography (MVCT) in TomoTherapy devices forces to test the correctness of the detection system operation. Correct work of the MV detector determines the precise positioning of the patient on the treatment table and accurate delivery of the planned dose to the irradiated area by faithfully reproducing the shape of the planning treatment volume (PTV) and critical organs. The quality assurance (QA) of the detector's work is necessary to ensure correct implementation of treatment plans. The vast amount of data obtained from the tests makes it increasingly popular to use software that automatically performs the analysis. This paper was aimed at justification of the ARTISCAN software 
implementation to semi-automatic analysis of MVCT parameters, indication of the method for determining tolerance and its establishment for selected physical quantities describing the quality of tomographic images, and determination of their precision.

Stowa kluczowe: tomoterapia, megawoltowa tomografia komputerowa, kontrola jakości, ARTISCAN

Keywords: tomotherapy, megavoltage computed tomography, quality assurance, ARTISCAN

\section{Wstęp}

Kontrola jakości we współczesnej medycynie jest niezwykle istotna. Szereg procedur sprawdzających poprawność działania wykorzystywanych systemów i urządzeń pozwala na rzetelne i bezpieczne leczenie pacjentów.

Odkrycie promieniowania rentgenowskiego, a następnie jego wykorzystaniew diagnostyce obrazowej, pozwoliło na szybki rozwój całej medycyny. Obrazowanie w radioterapii jest istotne, ponieważ pozwala kontrolować ułożenia pacjenta na stole terapeutycznym tuż przed napromienianiem lub w jego trakcie. Weryfikacja pozycji pacjenta zapewnia dokładniejsze dostarczenie zaplanowanej dawki terapeutycznej do PTV z jednoczesną ochroną wszystkich zdrowych tkanek oraz narządów krytycznych znajdujących się w pobliżu napromienianej objętości. Zapewnienie poprawności działania systemu obrazowania, w jakie wyposażone są akceleratory medyczne, jest zatem kluczowym elementem realizacji wysokospecjalistycznych procedur radioterapeutycznych [1-5]..

\section{Cel pracy}

Celem niniejszej pracy było uzasadnienie wdrożenia oprogramowania ARTISCAN do półautomatycznej analizy parametrów MVCT, wskazanie sposobu wyznaczenia tolerancji i ich ustalenie dla wybranych własności fizycznych opisujących jakość obrazów tomograficznych oraz określenie ich precyzji.

\section{Material}

Testy kontroli jakości detektora megawoltowego przeprowadzano dla akceleratora radioterapeutycznego TomoTherapy Hi-Art firmy Accuray. W badaniach wykorzystano fantom stały (Virtual Water Phantom - Cheese Phantom dostarczony przez firmę Accuray) z insertami (wkładami) o różnej gęstości fizycznej (Rycina 1).
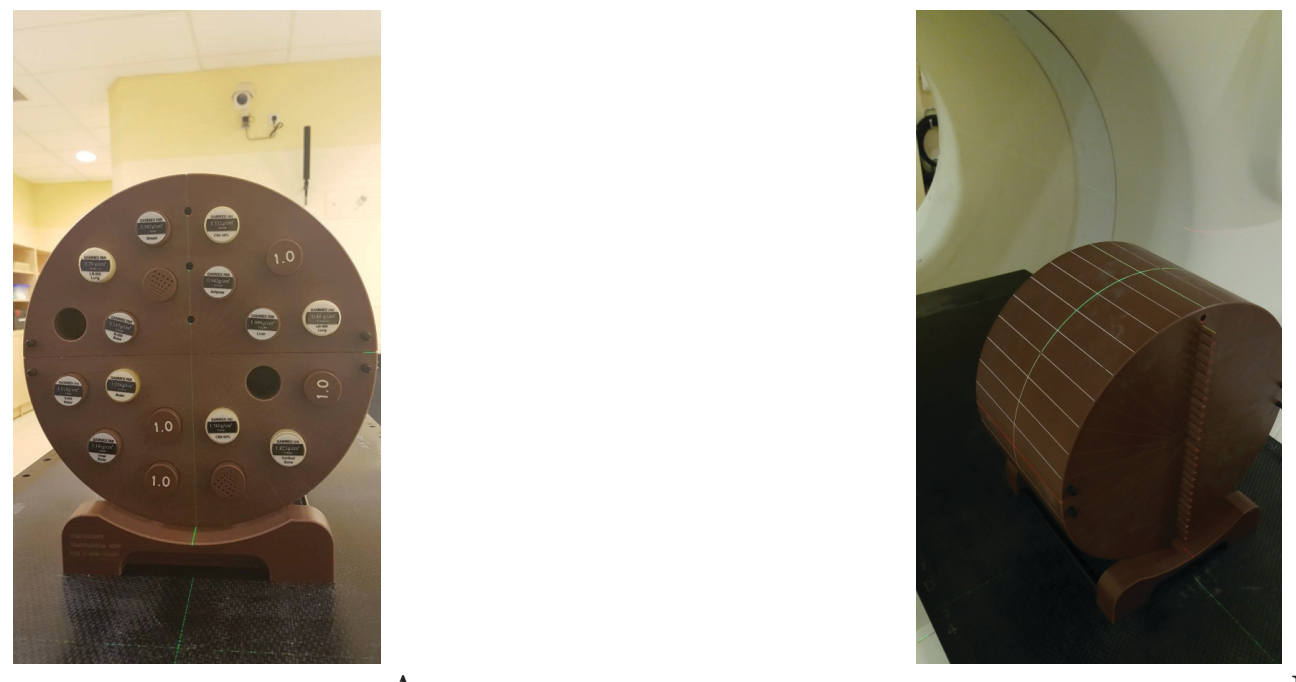

A

B

Rycina 1. Ustawienie Cheese Phantom z wkładami o różnej gęstości fizycznej na stole terapeutycznym

[Opracowanie własne]. 


\section{Metoda}

Fantom z insertami umieszczano na stole terapeutycznym w izocentrum wirtualnym (punkcie znajdującym się w odległości $70 \mathrm{~cm}$ od izocentrum rzeczywistego akceleratora). Centratory laserowe pokrywały się ze znacznikami na fantomie. Obszar skanowania zawierał się od $-10 \mathrm{~cm}$ do $10 \mathrm{~cm}$ względem środka fantomu. Skanowanie wykonano w trybie Normal z grubością warstwy $2 \mathrm{~mm}$. Dokładne wykonanie powyższych czynności zgodnie z określoną procedurą jest bardzo ważne, ponieważ wpływa na liczbę uzyskanych obrazów.

Dane matematyczne zebranych obrazów analizowano przy pomocy programu komputerowego ARTISCAN firmy AQUILAB. Przy pierwszym wykorzystaniu oprogramowania należało stworzyć protokół analizy, czyli przypisać konkretne skany fantomu do badanego parametru. Otrzymanie innej liczby obrazów przy kolejnym badaniu wymagało od użytkownika modyfikacji protokołu. Czynności te nie są czasochłonne i pozwalają na przeprowadzenie szybkiej analizy. W celu oceny parametru rozdzielczość przestrzenna użytkownik musiał każdorazowo wskazać dwa skrajne otwory w insercie. Bez tej czynności analiza ww. parametru nie byłaby możliwa. Przykładowy protokół kontroli jakości obrazowania megawoltowego przedstawiono na Rycinie 2.
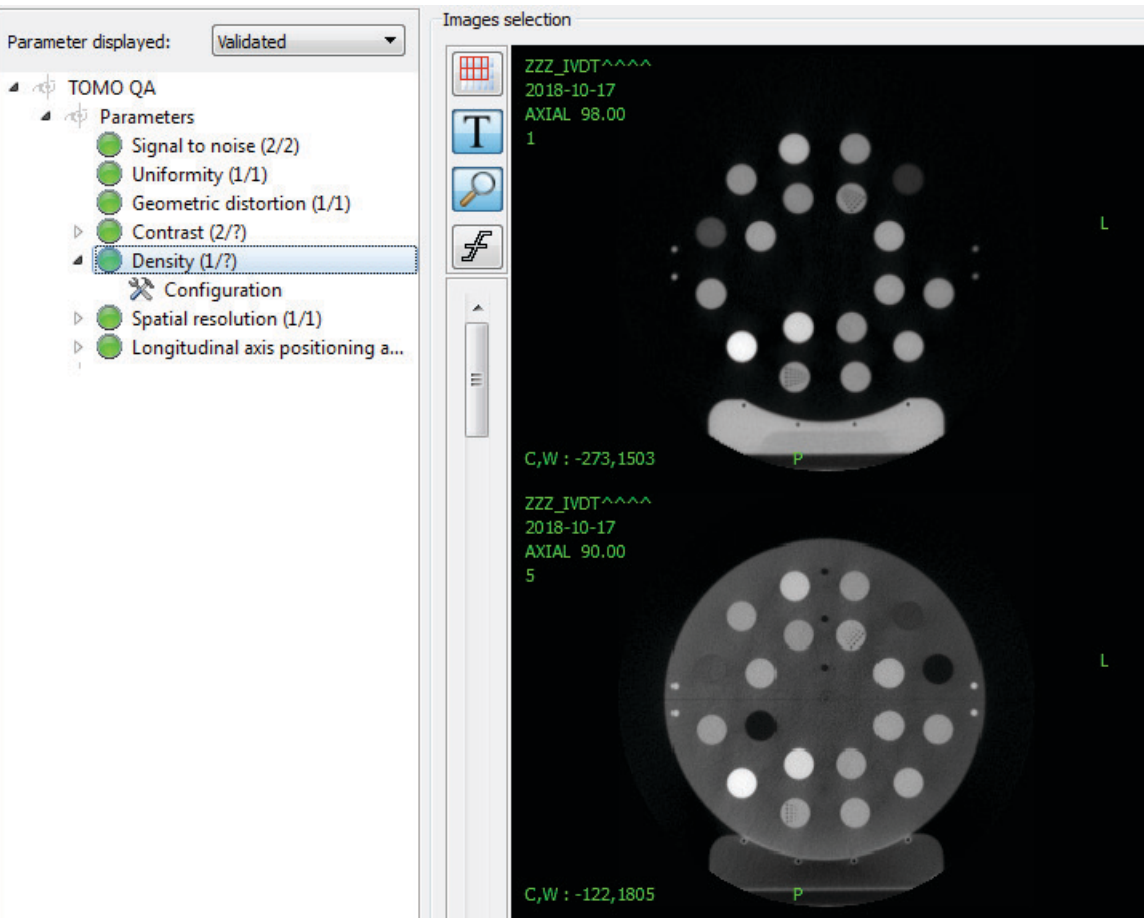

Rycina 2. Protokół kontroli jakości obrazowania megawoltowego [6].

Opisywane pomiary wykonywano 30-krotnie w czasie 7 miesięcy (liczba prób $n=30$ ). Precyzję wyrażającą powtarzalność metody analizy danych prowadzonej w ARTISCAN opisano za pomocą wyrażonego procentowo współczynnika zmienności Wz zgodnie z poniższą formułą:

$$
W_{z}=\frac{\mathrm{SD}}{\mathrm{S}_{\mathrm{a}}} * 100 \%[7]
$$

gdzie:

Wz - współczynnik zmienności [\%],

SD - odchylenie standardowe wartości badanej wielkości fizycznej [j.m.],

Śra - średnia arytmetyczna wartości badanej wielkości fizycznej [j.m.].

Im mniejszy współczynnik Wz tym większa precyzja wykorzystywanej metody. Powtarzalność otrzymywanych wyników świadczy nie tylko o precyzyjności procedury, ale również o stabilnej pracy badanego systemu obrazowania. Jeżeli współczynnik zmienności jest mniejszy niż 15\% to metodę uznaje się za precyzyjną [7]. 
Na podstawie uzyskanych danych wyznaczono tolerancje (średnia \pm 2 SD) badanych parametrów modułu MVCT. Przykładowy wynik analizy zebranych obrazów przedstawia Rycina 3.
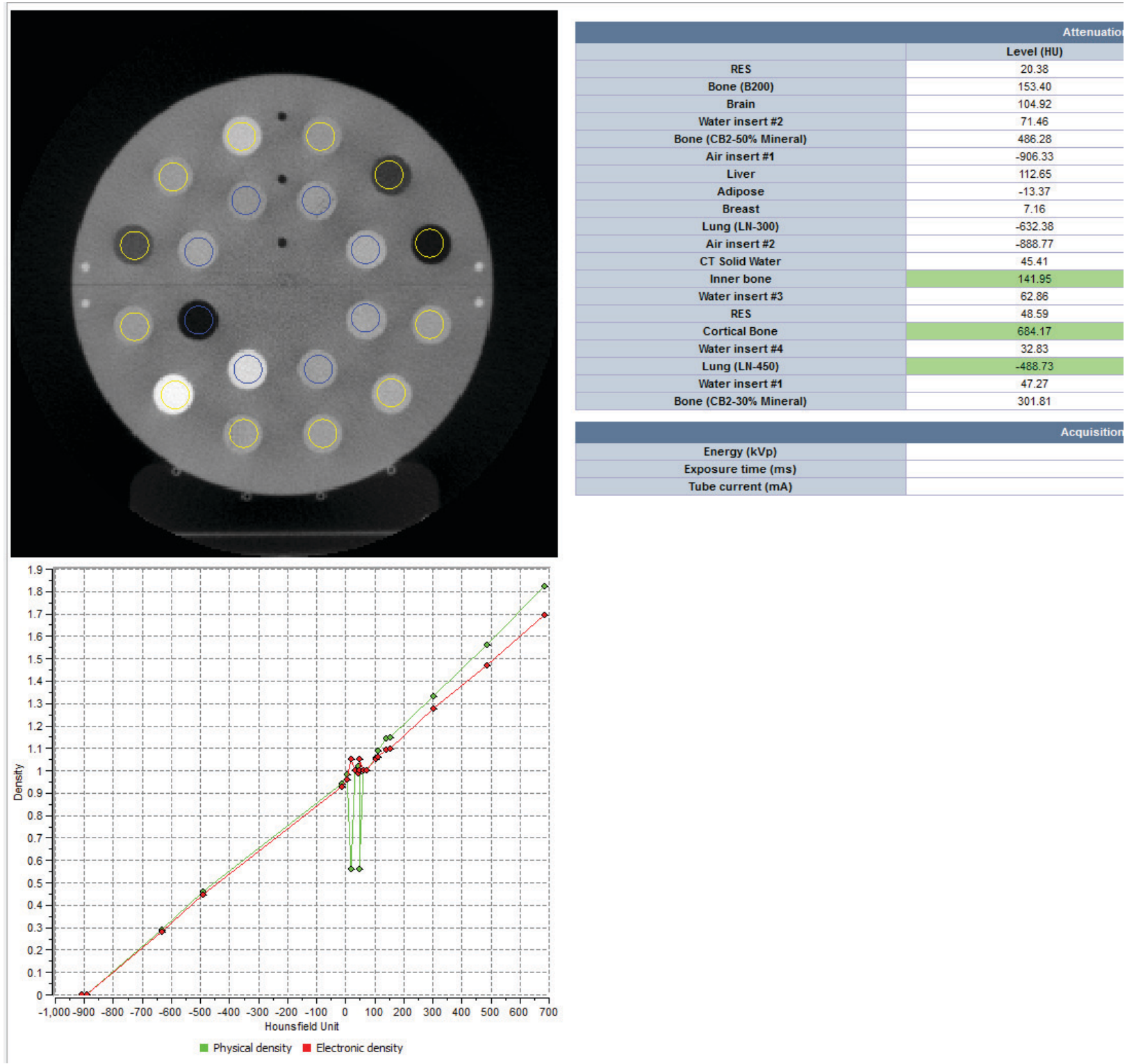

Rycina 3. Przykładowy wynik analizy zebranych obrazów dla parametru gęstość [6].

\section{Wyniki}

Tabela 1 przedstawia wyniki pomiarów: średnią arytmetyczną i precyzję badanych wielkości. Najmniejszą precyzję odnotowano dla parametru rozdzielczość przestrzenna dla dwóch insertów, dla największych analizowanych otworów (wartości Wz odpowiednio 18,63\% i 21,75\%). Pozostałe wielkości charakteryzowały się wyższą powtarzalnością wyników, o czym świadczyła wartość współczynnika Wz nieprzekraczająca 10,95\% (wynik uzyskany dla parametru kontrast - istota gąbczasta kości).

Uwagę należy zwrócić również na jednorodność, a dokładnie obszar 1 (0,71\%), ponieważ jest to wielkość opisująca homogeniczność całego przekroju tomograficznego.

Najmniejszym współczynnikiem Wz (o,02\%), a tym samym największą precyzją, charakteryzował się parametr zniekształcenie geometryczne - średnia wartość. 


\begin{tabular}{|c|c|c|}
\hline PARAMETR & WIELKOŚĆ & $\begin{array}{c}\text { ŚREDNIA (PRECYZJA } \\
\text {-Wz [\%]) }\end{array}$ \\
\hline \multirow{5}{*}{ Stosunek sygnału do szumu } & Obszar 1 & $64,45(1,06)$ \\
\hline & Obszar 2 & $73,52(3,72)$ \\
\hline & Obszar 3 & $76,17(2,74)$ \\
\hline & Obszar 4 & $74,52(3,66)$ \\
\hline & Obszar 5 & $74,43(3,08)$ \\
\hline \multirow{9}{*}{ Jednorodność [\%] } & Obszar 1 & $92,18(0,71)$ \\
\hline & Obszar 2 & $97,4(0,29)$ \\
\hline & Obszar 3 & $97,3(0,28)$ \\
\hline & Obszar 4 & $97,31(0,32)$ \\
\hline & Obszar 5 & $97,44(0,28)$ \\
\hline & Profil 1 & $95,09(0,86)$ \\
\hline & Profil 2 & $95,08(0,72)$ \\
\hline & Profil 3 & $96,61(0,36)$ \\
\hline & Profil 4 & $96,64(0,39)$ \\
\hline 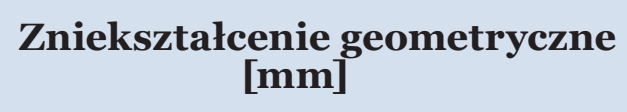 & Średnia wartość & $302,35(0,02)$ \\
\hline \multirow{3}{*}{ Gęstość [HU] } & Płuco 450 & $-498,84(2,00)$ \\
\hline & Istota gąbczasta kości & $128,26(7,93)$ \\
\hline & Istota zbita kości & $677,33(1,56)$ \\
\hline \multirow{3}{*}{ Kontrast } & Pluco 450 & $-31,86(6,87)$ \\
\hline & Istota gąbczasta kości & $8,22(10,95)$ \\
\hline & Istota zbita kości & $43,36(8,44)$ \\
\hline \multirow{4}{*}{$\begin{array}{l}\text { Rozdzielczość przestrzenna - } \\
\text { Insert } 1[\mathrm{lp} / \mathrm{cm}]\end{array}$} & LP75 & $0,51(18,63)$ \\
\hline & LP5O & $1,01(16,34)$ \\
\hline & LP25 & $1,32(6,82)$ \\
\hline & LP10 & $1,48(6,76)$ \\
\hline \multirow{4}{*}{$\begin{array}{l}\text { Rozdzielczość przestrzenna - } \\
\text { Insert } 2[1 p / c m]\end{array}$} & LP75 & $0,46(21,74)$ \\
\hline & LP5O & $0,9(18,89)$ \\
\hline & LP25 & $1,24(9,27)$ \\
\hline & LP10 & $1,48(8,78)$ \\
\hline
\end{tabular}

Tabela I. Wyniki analizy obrazów uzyskanych dla akceleratora TomoTherapy [Opracowanie własne]. 
Program ARTISCAN umożliwia monitorowanie zachodzących w czasie zmian badanych parametrów. Na Rycinie 4 przedstawiono zmienność wyników pomiarów dla parametru jednorodność, obserwowaną w czasie 7 miesięcy.

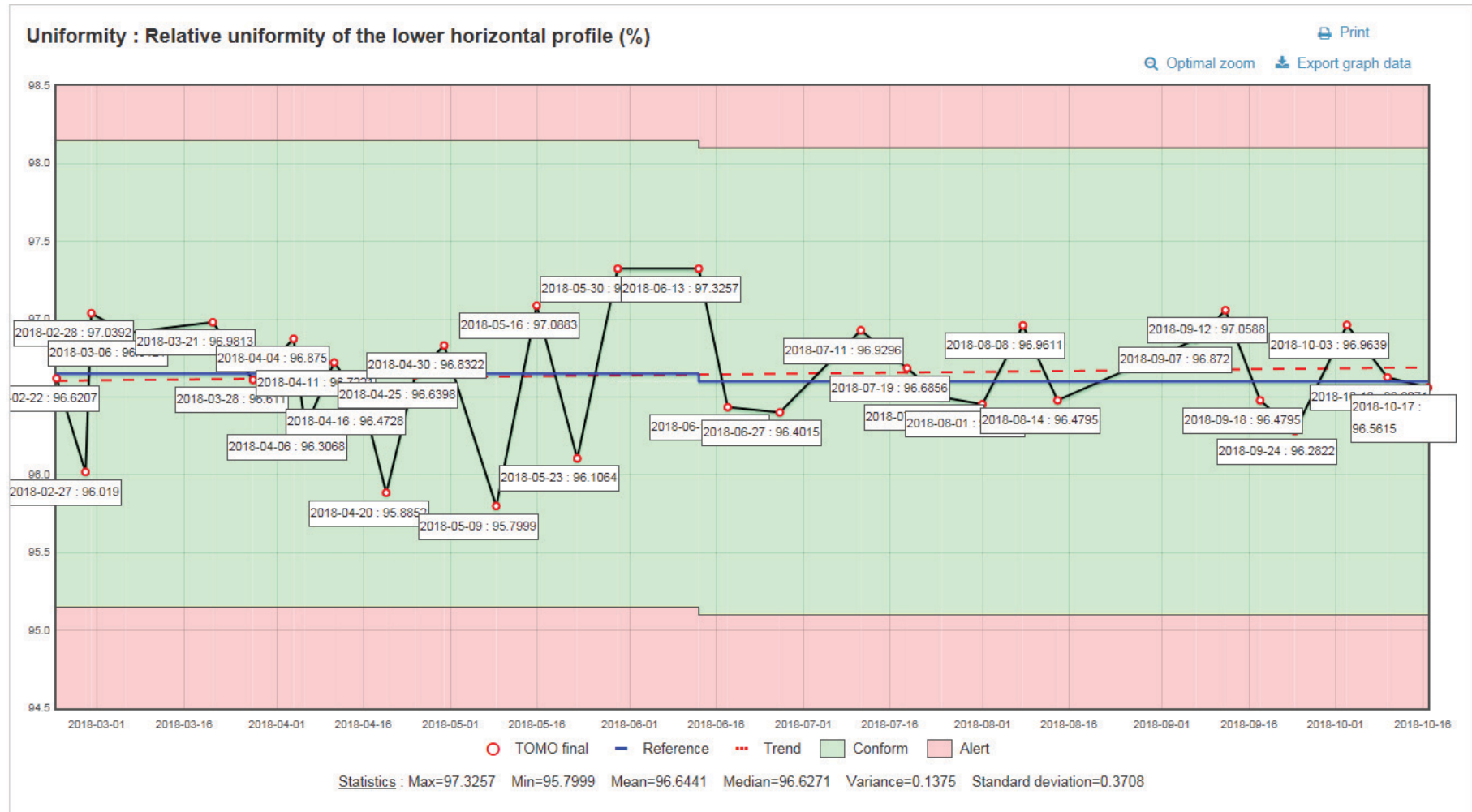

Rycina 4. Zmienność wyników jednorodności obrazowania megawoltowego [6].

\section{Dyskusja wyników}

Badane w pracy parametry megawoltowej tomografii komputerowej są bardzo ważne z praktycznego punktu widzenia. Informują one o jakości obrazów, które służą kontroli ułożenia pacjenta na stole terapeutycznym podczas napromieniania. Uzyskanie wysokiej jakości obrazów przyczynia się dokładnej realizacji planu leczenia, m.in. dostarczeniu zaplanowanej dawki do PTV oraz ochronie zdrowych tkanek i narządów krytycznych. Finalnie prowadzi to do zwiększenia efektywności i bezpieczeństwa terapii.

W niniejszej pracy przedstawiono możliwości zastosowania oprogramowania ARTISCAN do półautomatycznej analizy parametrów obrazów MVCT. Program komputerowy umożliwia użytkownikowi samodzielną ocenę poprawności działania systemu obrazowania. Dla większości parametrów wyniki uzyskano w sposób automatyczny i bez ingerencji użytkownika. Skutkowało to uzyskaniem parametrów charakteryzujących się wysoką precyzją o czym świadczył współczynnik Wz nieprzekraczający $10,95 \%$. Najwyższa precyzja występowała dla zniekształcenia geometrycznego. Wynikało to najprawdopodobniej z niezmiennego fizycznego wymiaru fantomu. Jedynym parametrem, który wymagał większego udziału użytkownika była rozdzielczość przestrzenna. W tym przypadku użytkownik musiał sam zaznaczyć punkty do analizy. Trudność dokładnego wskazania skrajnych elementów insertu przekładała się na większy rozrzut wyników w porównaniu do innych parametrów.

Precyzyjność metody analizy obrazów MVCT jest niezwykle istotna. Pojawienie się najmniejszych artefaktów na skanach fantomu, wynikających z błędnego działania systemu obrazowania, powodowało, że wyniki badanych wielkości fizycznych znajdowały się poza wyznaczonymi tolerancjami. 


\section{Wnioski}

Program ARTISCAN pozwala na szybką i półautomatyczną analizę parametrów obrazowania megawoltowego akceleratora TomoTherapy Hi-Art. Stwierdzono, że wykorzystana metoda analizy danych jest precyzyjna. Wyznaczono tolerancje dla badanych wielkości fizycznych opisujących obrazy tomograficzne. Wykorzystane oprogramowanie umożliwia fizykowi medycznemu samodzielną kontrolę poprawności działania detektora megawoltowego.

\section{Konflikt interesu/ Conflict of interest}

Nie występuje / None

\section{Finansowanie/ Financial suport}

Nie występuje / None

\section{Etyka/ Ethics}

Treści przedstawione w artykule są zgodne z zasadami Deklaracji Helsińskiej, dyrektywami EU oraz ujednoliconymi wymaganiami dla czasopism biomedycznych.

\section{Piśmiennictwo / References}

[1] Klein E, Hanley J, Bayouth J i wsp. Task Group 142 report: Quality assurance of medical accelerators. Medical Physics, 2009, Vol. 36, No. 9, 4207-4208.

[2] Langen K, Papanikolaou N, Balog J i wsp. QA for helical tomotherapy: Report of the AAPM Task Group 148. Medical Physics, 2010, Vol. 37, No. 9, 4835-4838.

[3] Zhu J, Bai T, Gu J, Sun Z, Wie Y, Li B, Yin Y. Effects of megavoltage computed tomographic scan methodology on setup verification and adaptive dose calculation in helical TomoTherapy. Radiation Oncology, 2018, 13:80.

[4] Langen K, Meeks S, Poole D, Wagner T. et al. The use of megavoltage CT (MVCT) images for dose recomputations. Physics in Medicine and Biology, 2005, Vol. 50, 4259-4276.

[5] Bąk B, Adamska A, Kaźmierska J, Piotrowski T. Nowoczesne metody radioterapii - tomoterapia. Inżynier i Fizyk Medyczny, 6/2014, Vol. 3.

[6] Oprogramowanie ARTISCAN wersja 4.4.1.

[7] Polski koncern normalizacyjny, Dokładność (poprawność i precyzja) metod pomiarowych i wyników pomiarów -- Część 2: Podstawowa metoda określania powtarzalności i odtwarzalności standardowej metody pomiarowej. PN-ISO 5725-2:2002. 